\title{
FUNGSI SOSIAL, STRUKTUR, DAN CIRI KEBAHASAAN TEKS IKLAN DI LANSKAP LINGUISTIK SEKOLAH: KAJIAN TEORI LINGUISTIK SISTEMIK FUNGSIONAL
}

\author{
SOCIAL FUNCTIONS, STRUCTURE, AND LANGUAGE FEATURES OF \\ ADVERTISING TEXTS IN SCHOOL LINGUISTIC LANDSCAPES: STUDY OF \\ FUNCTIONAL SYSTEM LINGUISTIC THEORY
}

\section{Hidayat Widiyanto, Emzir, Liliana Muliastuti \\ Universitas Negeri Jakarta}

Jalan Rawamangun Muka Raya No.11, RW.14, Rawamangun, Kec. Pulo Gadung, Kota Jakarta Timur, Daerah Khusus Ibukota Jakarta

Ponsel: 0818487628; Pos-el: hidayatWidiyanto_7316168014@mhs.unj.ac.id;

emzir.unj@unj.ac.id; liliana.muliastuti@unj.ac.id

\begin{abstract}
Abstrak
Tujuan tulisan ini ialah untuk melihat teks iklan di lingkungan sekolah berdasarkan teori Linguistik Sistemik Fungsional yang difokuskan pada fungsi sosial, struktur teks, dan ciri kebahasaan teks iklan. Metode penelitian ini menggunakan analisis isi Philip Myring dengan pengembangan kategori induktif. Teks iklan yang dipajang di sekolah menyampaikan produk dalam bidang pendidikan, minuman, dan kosmetik dan memiliki struktur teks iklan yang lengkap sebagai teks eksposisi, serta penggunaan bahasa yang sesuai dengan bahasa pada iklan. Fungsi sosial iklan selain memasarkan produk juga memberikan pesan lain. Teks iklan di sekolah dapat berimplikasi pada model pembelajaran di dalam kelas atau penguasaan teks iklan siswa dapat digunakan dalam penyusunan iklan yang dipasang di sekolah.
\end{abstract}

Kata-kata kunci: lanskap; linguistik; teks iklan; sekolah

\begin{abstract}
The purpose of this paper is to observe the advertising text in a school environment based on the theory of Linguistics Functional which focuses on social functions, text structure, and linguistic features. This research method uses Philip Myring content analysis with the development of inductive categories. The advertising text displayed in schools communicates products in the fields of education, beverages, and cosmetics and has a complete text structure as an exposition text, as well as the use of language features in the advertisement text. The social function of advertisement is not only to trade the product but also to to provide other messages. Advertising texts in schools
\end{abstract}


implicate in class learning models or in other words, student competetence that can be used in a good advertisement texts posted in schools.

Keywords: landscape; linguistic; advertisement text; school

\section{Pendahuluan}

Landry dan Bourhis (1997) memberikan batasan lanskap linguistik merupakan bahasa yang digunakan pada rambu jalan, papan reklame, nama jalan, nama tempat, rambu toko komersial, rambu umum di gedung-gedung pemerintah yang membentuk sebuah lanskap suatu teritorial, wilayah, atau daerah urban tertentu. Mereka memberikan batasan penggunaan bahasa berupa penggunaan bahasa tertulis.

Konsep Landry dan Bourhis tersebut dapat ditarik ke sebuah kawasan tertentu, termasuk di sekolah. Penelitian penggunaan bahasa di lingkungan sekolah menggunakan istilah schoolscape (Brown, 2005). Penelitian itu mulai berkembang sejak tahun 2005 yang diangkat oleh Brown yang mengaitkan antara sekolah dan lanskapnya. Sekolah merupakan lokus utama pembelajaran siswa. Secara ideal tempat pembelajaran sebaiknya mendukung pendidikan dan pemelajaran. Lanskap linguistik di lingkungan sekolah ini merupakan bagian yang tidak kalah pentingnya untuk dibahas dalam kajian akademik, direncanakan sesuai dengan kebijakan yang ada, dan dapat menjadi alat pembelajaran siswa. Oleh karena itu, lanskap lingkungan sekolah dapat dikaji secara akademis untuk mendukung proses pendidikan tersebut.

Beberapa penelitian yang membahas kaitan penggunaan bahasa di lingkungan sekolah dengan kepentingan pendidikan telah banyak dipublikasikan. Lanskap linguistik dapat menambah kekritisan siswa dalam menerima pembelajaran (Sayer, 2009). Lanskap linguistik sekolah digunakan sebagai alat pendidikan untuk meningkatkan literasi siswa yang diwujudkan siswa melalui karya mereka (Hewitt-Bradshaw, 2014). Lanskap linguistik sekolah dapat meningkatkan kepedulian berbahasa dan berkontribusi pada kompetensi multilingual siswa (Gorter-Cenoz, 2015). Pola komunikasi dan kompetensi bahasa siswa dapat dipengaruhi oleh penggunaan bahasa di lingkungan sekolah sehingga kondisi tersebut juga mempengaruhi pemerolehan bahasa anak-anak tersebut (Scarvaglieri, 2017).

Berdasarkan laporan dari 
berbagai akademisi tersebut penggunaan bahasa di lingkungan sekolah perlu mendapat perhatian serius. Penggunaan bahasa di lanskap linguistik tersebut dapat berupa iklan yang terpajang di lingkungan sekolah. Fungsi iklan itu tidak hanya menyampaikan pesan isi iklan tersebut untuk kepentingan pemasaran barang atau jasa tetapi juga dapat dijadikan model sebagai bahan pembelajaran di kelas VIII karena Kurikulum 2013 sebagai kurikulum pendidikan di Indonesia menetapkan teks iklan termasuk dalam kompetensi dasar (KD). KD tersebut meliputi 3.3 mengidentifikasi informasi teks iklan, slogan, atau poster dari berbagai sumber yang dibaca dan didengar; 4.3 menyimpulkan isi iklan, slogan, atau poster dari berbagai sumber; 3.4 menelaah pola penyajian dan kebahasaan teks iklan, slogan, atau poster dari berbagai sumber yang dibaca dan didengar; 4.4 menyajikan gagasan, pesan, dan ajakan dalam bentuk iklan, slogan, atau poster secara lisan dan tulis. Oleh karena itu, teks iklan di lingkungan SMP tidak hanya berfungsi sebagai alat untuk menyampaikan pesan, tetapi juga dapat dijadikan materi pemelajaran dan dapat digunakan sebagai bahan peningkatan pemahaman siswa terhadap materi teks iklan.

Beberapa penelitian tentang iklan di sekolah telah dilakukan oleh para guru di Indonesia. Peserta didik merasa kesulitan dalam memahami materi teks iklan, slogan, dan poster, kesulitan untuk mencari ide dan kata-kata, serta kurang termotivasi telah dilakukan di Indonesia (Maulidina, Y. R. dan Trinil Dwi Turistiani, 2018). Satu penelitian mengangkat struktur wacana iklan di berbagai media cetak (Tugiati-Kuntoro, 2019). Dalam penelitian tersebut iklan diambil dari sumber media cetak. Analisis fungsi sosial yang berbasis pada Linguistik Sistemik Fungsional menyatakan bahwa fungsi iklan pada produk susu yang diteliti berfungsi untuk memperkenalkan, memberi informasi, dan memasarkan produk dengan tujuan menarik konsumen. Kedua iklan susu formula yang diteliti memiliki genre deskripsi dan genre eksposisi. Penjelasan fungsi produk menggunakan proses material dan lebih banyak menggunakan kalimat pasif.

Berdasarkan penelitian tersebut perlu ada penelitian untuk mempermudah peserta didik menangkap informasi, kelengkapan struktur, dan ciri kebahasaan dalam sebuah iklan sehingga informasi tersebut mempermudah 
mereka dalam memahami dan memproduksi teks iklan.

Berdasarkan latar belakang yang tersebut, baik dari aspek lanskap linguistik maupun substansi iklan sebagai bahan pemelajaran, tulisan ini perlu diangkat. Temuan penelitian ini akan menguatkan relasi antara penggunaan bahasa dan lingkungan sekolah, serta lingkungan sekolah yang mendukung proses pembelajaran di kelas. Fokus penelitian ini terletak pada teks iklan di lingkungan sekolah. Iklan tersebut akan dibahas melalui basis linguistik fungsional yang mendasari pemelajaran berbasis teks yang meliputi fungsi sosial, struktur, dan ciri kebahasaan teks tersebut.

\section{Landasan Teori}

Berikut ini akan diuraikan perihal iklan di sekolah melalui pengertian iklan, fungsi sosial iklan di sekolah, struktur teks iklan, dan unsur kebahasaan teks iklan.

Arens, Williams dkk. (2010) mendefinisikan iklan merupakan komunikasi nonpersonal yang terstruktur yang persuasif tentang produk melalui media massa. Iklan sebagai segala bentuk penyampaian nonpersonal dan penyampaian gagasan, barang, atau jasa melalui sponsor tertentu. Iklan diharapkan sebagai media untuk mengubah perilaku konsumen dalam menentukan dan memutuskan proses sampai dengan target membeli dan memanfaatkan produk yang disampaikan. Selanjutnya, Shulz dkk. (1996) memberikan informasi tentang pesan penjualan yang efektif untuk memanggil setiap calon pembeli secara langsung. Pemasar umumnya dapat menjangkau lebih banyak prospek dengan lebih efisien dan lebih efektif melalui sistem ini daripada melalui sistem lain.

Tiga pemahaman tersebut memberikan kata kunci bahwa iklan merupakan sebuah komunikasi nonpersonal yang bersifat persuasif yang efektif untuk sebuah barang, jasa, atau ide. Jadi, teks iklan di sekolah merupakan sebuah teks tentang produk barang, jasa, atau ide yang disampaikan secara persuasif di lingkungan sekolah. Teks ini berada di lingkungan sekolah yang dapat digolongkan pada lanskap linguistik sekolah.

Teks iklan memiliki ciri yang membedakan dengan teks lainnya. Ciriciri tersebut antara lain memiliki sasaran dan target tertentu, fokus terhadap barang dan jasa yang diiklankan, 
memiliki unsur daya tarik yang dapat disampaikan melalui pemakaian bahasa dan desain yang menarik. Fungsi sosial yang bersifat persuasif terhadap barang atau jasa yang disampaikan menjadi target utama informasi tersebut. Pembaca iklan akan menyetujui, membenarkan, dan memakai produk barang dan jasa pada akhirnya. Selain itu, fungsi lain juga dapat menempel pada iklan ini. Fungsi lain inilah yang dapat menempel pada iklan di sekolah.

Berikut ini dijelaskan struktur umum teks iklan yang merupakan bagian dari struktur teks eksposisi. Genre teks iklan dicirikan dengan tiga bagian struktur teks (Agustien, 2020:25). Tiga unsur tersebut meliputi unsur berikut.

1) Orientasi yang dapat berupa judul atau tajuk iklan, yaitu bagian utama iklan yang diletakkan di awal atau atas bagian teks.

2) Tubuh iklan atau argumen yang dapat berisi nama produk atau jasa, yaitu barang atau jasa yang ditawarkan kepada pembaca atau penerima pesan.

3) Justifikasi atau rekomendasi, yaitu bagian yang berisi penjelasan terhadap barang atau jasa yang ditawarkan. Informasi ini dibuat menarik singkat, padat dan efektif.
Ciri kebahasaan yang digunakan dalam teks iklan adalah penggunaan kata yang tepat, menarik, logis serta sopan, penggunaan daya ungkap sugesti yang kuat dan hanya menggunakan informasi penting dan pendek. Kosasih (2017) menambahkan bahwa setidaknya ada ada lima unsur pembentuk unsur kebahasaan dalam teks iklan. Unsur tersebut adalah sebagai berikut (1) bahasa yang digunakan bersifat persuasif, (2) struktur kalimat imperatif, (3) pilihan kata sederhana dan mudah dipahami, (4) pilihan kata berima, dan (5) struktur singkat. Yang perlu diingat konsep dalam sebuah iklan adalah padat, singkat, dan jelas. Struktur kalimat yang panjang akan menyulitkan penerima dalam menangkap pesan.

$$
\text { Sudarwati dan Grace (2016) }
$$
memberikan ciri kebahasaan teks iklan dalam beberapa hal. Hal tersebut hampir sama dengan penjelasan sebelumnya di antaranya bahwa teks iklan sebaiknya memiliki bahasa yang bersifat evokatif seperti slogan, informatif, persuasif, penggunaan kata yang kuat, sederhana dan mudah dipahami, menggunakan kalimat aktif atau imperatif, dan memiliki kesan positif. Oleh karena itu, pembuat iklan dituntut memiliki kesadaran yang tinggi dalam 
penggunaan bahasa atas produk barang atau jasa yang akan dipasarkan.

\section{Metode Penelitian}

Pendekatan yang digunakan dalam menjawab penelitian ini adalah pendekatan kualitatif dengan metode analisis isi (content analysis) model Philipp Mayring. Jenis analisis isi yang digunakan menggunakan analisis isi kualitatif (Mayring, 2000) dengan pengembangan kategori induktif. Kategori yang dimaksud meliputi fungsi sosial, struktur teks, dan kaidah kebahasaan. Kategori didefinisikan, dikembangkan untuk aspek interpretasi dan merumuskan materi. Dalam penelitian ini data diambil melalui foto. Teks iklan dituliskan kembali dan dianalisis yang berfokus pada aspek fungsi sosialnya, struktur teks, unsur kebahasaan.

Data diambil dari salah satu sekolah di Jakarta, yaitu teks iklan cetak yang dipajang di lingkungan SMPN 44 Jakarta dan waktu pengambilan data dilakukan pada Agustus 2020. SMPN 44 Jakarta berlokasi di Jalan Gading Raya VII, Pisangan Lama, Kecamatan Pulo Gadung, Jakarta Timur. Data ini diambil dari sekolah negeri di Jakarta dan memiliki nilai akreditasi A.

\section{Pembahasan}

Secara umum objek bahasa di lanskap SMPN 44 Jakarta berjumlah 223 objek penggunaan bahasa. Iklan berjumlah 5 objek yang berada di gedung lama berjumlah 3 objek dan di gedung baru 2 objek iklan. Objek yang memberikan kontribusi besar dalam aspek kuantitatif di lanskap linguistik sekolah didominasi teks slogan.

Pembahasan lima teks iklan akan diuraikan dalam pembahasan fungsi sosial, struktur teks, dan penggunaan bahasanya. Uraian penjelasan secara terperinci dapat disampaikan dalam informasi berikut.

\section{Data 1}

Fungsi sosial iklan merupakan pesan yang disampaikan iklan tersebut kepada pembacanya. Hal itu bisa terlihat dari ukuran huruf paling besar dalam komposisi iklan tersebut. Tiga informasi yang mewakili informasi penting dalam iklan tersebut ditampilkan dengan ukuran huruf paling besar, yaitu "Yayasan Maritim Pembangunan, Akademi Maritim Pembangunan, dan SMK Pelayaran Pembangunan". Fungsi iklan mengajak siswa sekolah untuk meneruskan pendidikannya di SMK Pelayaran Pembangunan. Iklan memberikan pesan kepada masyarakat 
umum, tetapi dipasang di SMPN 44 dapat dimaknai bahwa iklan ini menyasar anak kelas IX di kelas tersebut. Tidak terdapat fungsi lain selain menyampaikan informasi sekolah.

Struktur teks Data 1 dapat disampaikan melalui Tabel Struktur
Teks Data 1 berikut ini. Struktur yang biasa dan lengkap dalam sebuah iklan meliputi orientasi^tubuh iklan^justifikasi. Untuk itu, pembagian struktur pada teks pada Data 1 dapat dilihat dari tabel berikut ini.

Tabel 1 Struktur Teks Data 1

\begin{tabular}{|c|c|}
\hline Struktur Teks & Teks \\
\hline \multirow[t]{2}{*}{ Orientasi } & $\begin{array}{l}\text { Berdiri sejak tahun } 1985 \\
\text { Call center } 021-8412557\end{array}$ \\
\hline & $\begin{array}{l}\text { Yayasan Maritim Pembangunan } \\
\text { Menerima Pendaftaran Calon Taruna Baru dan Pindahan T.A } \\
\text { 2020/2021 }\end{array}$ \\
\hline \multirow[t]{2}{*}{ Tubuh iklan } & $\begin{array}{l}\text { Bergabunglah bersama kami DIKLAT MARITIM } \\
\text { PEMBANGUNAN untuk meraih cita-cita Perwira Kapal } \\
\text { Niaga Nasional dan Internasional serta mendukung POROS } \\
\text { MARITIM DUNIA. }\end{array}$ \\
\hline & $\begin{array}{l}\text { Akademi Maritim Pembangunan } \\
\text { Program Diploma } 3 \text { (D-III) : } \\
\text { 1. Nautika (Deck Officer Class III/ANT-III) } \\
\text { 2. Teknika (Engine Officer Class III/ATT-III) } \\
\text { 3. Ketatalaksanaan Pelayaran Niaga dan Kepelabuhan } \\
\text { (KPN-K) } \\
\text { SMK Pelayaran Pembangunan } \\
\text { Program Studi } \\
\text { 1. Nautika Kapal Niaga (Deck Officer Class IV/ANT- } \\
\text { IV) } \\
\text { 2. Teknika Kapal Niaga (Engine Officer Class IV/ATT- } \\
\text { IV) }\end{array}$ \\
\hline Justifikasi & $\begin{array}{l}\text { Sekretariat Pendaftaran } \\
\text { Lokasi strategis }+/-50 \mathrm{M} \text { terminal Kampung Rambutan } \\
\text { Jl. Manunggal II No 67 Ciracas Jakarta Timur } 13830 \\
\text { Telp/fax : 021-8412557,87799309 } \\
\text { Email: } \quad \text { ampjkt@gmail.com } \\
\text { smkppembangunan@gmail.com } \\
\text { Website : www.smkpp.sch.id } \\
\text { \#maritimpembangunan@amp_smkp } \\
\text { Kontak Person: } \\
\text { Nickholas (081295951836) } \\
\text { Ariawan (081387694446) } \\
\text { Anton(0895322335747) } \\
\text { Pendaftaran Online: } \\
\text { bit.ly/PPDBOnline2020 }\end{array}$ \\
\hline
\end{tabular}


Struktur teks Data 1 dapat disampaikan melalui informasi berikut. Bagian orientasi teks iklan berupa "Yayasan Maritim Pembangunan Menerima Pendaftaran Calon Taruna Baru dan Pindahan T.A 2020/2021". Bagian pembuka teks ini sesuai dengan kaidah struktur teks iklan sebagai pengantar atau pembuka teks iklan. Selanjutnya, pada bagian struktur ini pembaca diajak untuk bergabung dalam Yayasan Maritim Pembangunan sebagai peserta didik dan mahasiswa. Bagian tubuh iklan di atas berupa produk yang ditawarkan berupa pendidikan di 1) Akademi Maritim Pembangunan dan 2) SMK Pelayaran Pembangunan. Kedua produk yang ditawarkan dilengkapi dengan informasi berupa jurusan pada setiap jenjang pendidikan tersebut. Bagian justifikasi berupa informasi penjelas produk seperti spesifikasi, cara mendapatkan informasi selanjutnya, alamat dan nomor yang dapat dihubungi. Bagian justifikasi iklan tersebut berisi alamat dan kontak narahubung untuk mempermudah komunikasi tindak lanjut iklan tersebut. Secara struktur iklan tersebut memenuhi ketiga bagian dari teks iklan berupa orientasi^ ${ }^{\wedge}$ tubuh iklan^justifikasi. Oleh karena itu, Data 1 dapat disimpulkan memenuhi semua bagian struktur teks iklan yang lengkap.

Kaidah kebahasaan teks iklan pada Data 1 dapat diulas sebagai berikut. Teks iklan ini bersifat persuasif dan menggunakan struktur imperatif ditandai dengan penggunaan kata "Bergabunglah bersama kami DIKLAT MARITIM PEMBANGUNAN untuk merah cita-cita Perwira Kapal Niaga Nasional dan Internasional serta mendukung POROS MARITIM DUNIA”. Pilihan kata yang digunakan sederhana kecuali pilihan kata teknis pada jurusan. Akan tetapi, bahasa yang digunakan tidak menunjukkan rima karena tidak menggunakan slogan dan tiga kalimat yang muncul dua di antaranya menggunakan kalimat simpleks.

Dalam iklan biasanya digunakan kata ganti subjek orang pertama sebagai acuan. Iklan tersebut menggunakan kata ganti "kami" untuk mengacu lembaga tersebut. Acuan tersebut menguatkan mereka sebagai lembaga yang mengiklankan informasi tersebut mengajak pembaca dan mewakili lembaga. Karena bersifat pengedepanan informasi dan sarat dengan pengedepanan aspek estetika dan komunikasi visual iklan, kaidah kebahasaan berupa penggunaan huruf 
kapital dan tanda baca tidak disesuaikan tata ejaan yang sesuai dengan Pedoman Umum Ejaan Bahasa Indonesia.

\section{Data 2}

Data 2 berisi informasi tentang lembaga pendidikan yang berjenjang SMA. Iklan tersebut dipasang di pagar sebelah kiri pintu gerbang yang ukuran kurang lebih 2 X 1 meter. Fungsi iklan ini bisa terlihat dari kalimat pertama sebagai pembuka iklan tersebut. "SMK MANDALA TIARA BANGSA Membuka Pendaftaran Peserta Didik Baru Tahun Ajaran 2020-2021”. Iklan ini ditujukan kepada masyarakat khususnya mengajak siswa kelas VIII yang akan lulus khususnya dari SMPN 44 Jakarta untuk meneruskan pendidikan di sekolah tersebut. Selain fungsi menyampaikan pesan pendaftaran terdapat pesan dengan slogan yang diusung berupa jika generasi sehat Indonesia akan unggul. Pesan inilah yang dapat ditangkap sebagai fungsi sosial.

Struktur Data 2 dapat disampaikan melalui Tabel Struktur Teks Data 2 berikut ini.

Tabel 2 Struktur Teks Data 2

\begin{tabular}{ll}
\hline Struktur Teks & Teks \\
\hline Orientasi & "SMK MANDALA TIARA BANGSA Membuka \\
& Pendaftaran Peserta Didik Baru Tahun Ajaran 2020- \\
& 2021" \\
& Buka informasi 09.00-13.00 Senin-Rabu \\
\hline Tubuh iklan & Fasilitas: Ruang kelas AC, Wifi, Apotek simulasi, LSP \\
& dan BAN-S/M \\
& Akreditasi "B", Keunggulan Kewirausahaan, Herbologi \\
& Bantuan :KJP, Bidik Mandala, BOS \\
\hline Justifikasi & Biaya Pendaftaran (Rp 200.000,-) \\
& Bebas (ketentuan berlaku) \\
& *Gel.I hingga bulan Mei 2020 \\
& Ayo Cepat Daftar \\
& Tempat Terbatas \\
& https://forms.gle/vEZJJkNF1p7hLxEx3 \\
& Whatsapp : \\
& 08990051900, \\
& 085719998359 08981280018, \\
& Jl. Persahabatan Raya No 16, Cipinang, Kec. Pulo \\
& Gadung, Kota Jakarta Timur 13240 \\
& Insatgram : @smkfarmasimtb \\
& Generasi Sehat \\
& Indonesia Unggul \\
& SMK Bisa \\
& SMK Hebat
\end{tabular}


Bagian orientasi teks iklan di atas berupa "SMK MANDALA TIARA BANGSA Membuka Pendaftaran Peserta Didik Baru Tahun Ajaran 20202021". Buka informasi 09.00-13.00 Senin-Rabu". Bagian pembuka teks ini sesuai dengan kaidah struktur teks iklan yang mengantarkan informasi produk.

Bagian tubuh iklan di atas berupa produk yang ditawarkan, yaitu pendidikan di SMK mandala Tiara Bangsa dengan spesifikasi keunggulan sekolah tersebut. Keunggulan yang ditawarkan berupa fasilitas yang baik, akreditasi sekolah yang cukup, dan fasilitas bantuan bagi siswa. Tiga informasi ini menjadi tubuh iklan yang sesuai dengan letaknya terdapat di tengah dari semua informasi.

Bagian justifikasi berupa informasi penjelasan produk seperti alamat, kontak narahubung, dan cara mendaftarkan diri di sekolah tersebut mengisi bagian justifikasi dan penutup iklan. Secara struktur iklan tersebut memenuhi ketiga bagian dari teks iklan berupa orientasi^^tubuh iklan^justifikasi. Oleh karena itu, iklan itu dapat disimpulkan memenuhi semua bagian struktur teks yang lengkap.

Kaidah teks iklan pada Data 2 dapat diulas sebagai berikut. Teks iklan secara umum memiliki beberapa kaidah kebahasaan, seperti penggunaan slogan yang berisi opini yang bisa menarik pelanggan untuk menggunakan barang atau jasa yang ditawarkan dalam iklan tersebut. Teks iklan pada Data 2 menutup iklannya pada justifikasi dengan dua slogan yang sangat relevan, yaitu "Generasi Sehat Indonesia Unggul" dan "SMK Bisa SMK Hebat". Kedua slogan mengarah pada ajakan persuasif. Sekolah yang menghasilkan lulusan yang andal dalam bidang farmasi akan memberikan dukungan dan membantu dunia kesehatan di Indonesia. Obat dan tata cara pengolahan dan pengelolaannya akan membantu perkembangan generasi yang sehat dan hal tersebut akan membuat generasi Indonesia menjadi unggul. Slogan kedua mengangkat bahwa anak yang bersekolah di SMK Tiara Mandala akan memiliki kompetensi karena sekolah tersebut bisa memberikan solusi dan membuat lulusannya menjadi hebat. Dua slogan ini juga menjadi kekuatan iklan ini karena membawa pilihan slogan yang kuat dan kontekstual meskipun tidak berima. Struktur kalimat sederhana diwakili hanya satu kalimat simpleks yang lain informasi berupa 
frasa sehingga memudahkan pembaca menangkap informasi.

Kalimat yang digunakan bersifat persuasif dapat dilihat melalui struktur kalimat berikut ini. "Ayo cepat daftar tempat terbatas". Penggunaan kalimat imperatif yang dimulai dengan "Ayo" sebagai penanda bahwa kalimat tersebut bersifat persuasif yang mengajak kepada pembacanya. Pada iklan tersebut tidak digunakan kata ganti orang. Karena bersifat pengedepanan informasi dan bukan kalimat resmi iklan tersebut tidak menggunakan tata ejaan yang sesuai dengan PUEBI.

\section{Data 3}

Data 3 berisi informasi tentang sebuah produk kopi yang dekat dengan anak muda. Iklan Ini tidak ada kaitannya dengan pendidikan tetapi berhubungan dengan usia penikmat kopi ini. Iklan tersebut dipasang di papan cincin basket di lapangan bola basket yang berada di lingkungan bangunan lama SMPN 44 Jakarta. Materi iklan tersebut berupa papan plat besi dengan ukuran 1 X 1,8 meter. Kedua papan pantul basket ini dipasang iklan yang sama dari produk kopi tersebut. Iklan ini lebih banyak menyampaikan aspek desain dan grafis atau gambar jika dibandingkan degan teks tulisnya.
Fungsi iklan ini bisa terlihat dari gambar minuman segelas kopi Good Day dengan es batu, dua bungkus kopi Good Day dengan pilihan rasa yang berbeda, dan slogan atau teks yang digunakan. "Kopi Dingin Ya Pake Air Dingin”. Dari gambar tambahan berupa embun dingin pembaca diajak menikmati dinginnya Good Day dengan campuran kopi dan es. Anak muda disasar sebagai peminum kopi dingin ini. Terdapat tiga informasi tulis berupa produk yang dipasarkan, slogan, dan alamat atau informasi tambahan.

Fungsi iklan Data 3 adalah pengajakan siswa sekolah untuk minum kopi dingin Good day. Fungsi teks ini berupa ajakan untuk minum kopi. Minum kopi dingin merupakan kebiasaan anak muda sesuai dengan tren kebiasaan minum kopi di masyarakat, khususnya anak muda. Oleh karena itu, tempat pemasangan iklan sangat kontekstual. Tidak ada pesan lain selain ajakan minum kopi produk tersebut dalam iklan itu.

Struktur teks Data 3 dapat disampaikan melalui Tabel Struktur Teks Data 3 berikut ini. Struktur yang biasa dan lengkap dalam sebuah iklan meliputi orientasi^tubuh 
Fungsi Sosial, Struktur, dan...

iklan^justifikasi. Untuk itu, pembagian

struktur pada teks di Data 3 berikut.

Tabel 3 Struktur Teks Data 3

\begin{tabular}{ll}
\hline Struktur Teks & Teks \\
\hline Orientasi & - \\
\hline Tubuh iklan & Good Day \\
& Coffee Freeze \\
\hline Justifikasi & Facebook : Good Day Coffee \\
& Twitter : @GoodDay ID \\
& www.hidupbanyakrasa.com \\
& Kopi Dingin Ya Pake Air Dingin \\
\hline
\end{tabular}

Teks ini tidak memiliki bagian orientasi. Teks langsung diisi dengan tubuh iklan berupa nama produk yang dipasarkan. Bagian tubuh iklan di atas berupa produk yang ditawarkan berupa produk minuman kopi Good Day dengan tambangan informasi Coffe Freeze. Kopi ini bertajuk Good Day yang sangat nikmat jika diminum dalam kondisi freeze atau dingin.

Bagian justifikasi berupa informasi penjelasan produk berupa alamat media sosial dan laman, serta satu slogan yang sangat dominan dalam tampilan iklan tersebut. Slogan yang disampaikan berupa "Kopi Dingin Ya Pake Air Dingin". Secara struktur iklan tersebut hanya memenuhi dua bagian, yaitu tubuh iklan^justifikasi. Oleh karena itu, Data 3 hanya memenuhi dua bagian dalam iklan akhir, tubuh iklan dan justifikasi dan tanpa orientasi.

Kaidah teks iklan pada Data 3 dapat diulas melalui informasi berikut ini. Teks iklan ini menggunakan slogan “Kopi Dingin Ya Pake Air Dingin”. Slogan ini mendominasi materi iklan ini. Hanya ada tiga bagian informasi tertulis dan slogan mendominasi ruang di iklan tersebut. Teks slogan yang tertulis tersebut ingin memberikan pemahaman baru kepada pembaca bahwa kopi ini adalah kopi yang diminum dalam kondisi dingin yang dicampur dengan es batu. Citra inilah yang ingin disampaikan dalam dua informasi dalam bahasa bahasa Inggris dan bahasa Indonesia yang keduanya memiliki makna yang sama. Slogan ini juga memberikan kesan kepada pembacanya bahwa kopi ini adalah kopi baru dalam produk minuman kopi untuk anak muda. Hal tersebut senada dengan informasi yang telah disampaikan Ahrens dkk (2010). Minuman kopi ini termasuk pada minuman ringan yang merupakan segmen iklan untuk anak muda usia 12-16 tahun. Kopi yang 
diminum dengan cara dingin dan dicampur dengan es batu merupakan cara baru untuk anak muda dan terasa ringan. Oleh karena itu, iklan ini cocok dengan lokusnya di sekolah.

Iklan ini tidak menampilkan kalimat yang bersifat persuasif dan menggunakan kalimat imperatif. Hanya pilihan kata sederhana hadir dalam iklan itu. Rima digunakan pada kata "dingin”. Struktur kalimat menggunakan struktur kalimat simpleks. Dalam iklan tersebut tidak digunakan kata ganti orang. Pilihan katanya juga menggunakan kalimat informal yang ringan digunakan oleh anak muda, seperti pake. Pilihan kata dalam bahasa Inggris mengedepankan rima agar mudah diingat oleh pembacanya, coffee dan freeze. Selain berima, makna yang disampaikan juga cocok dan tepat sehingga slogan dalam bahasa Inggris tersebut menjadi kekuatan yang sangat baik dalam kaidah bahasa iklan. Karena bersifat pengedepanan informasi dan menggunakan bahasa Inggris, iklan tersebut tidak menggunakan ejaan yang sesuai dengan PUEBI.

\section{Data 4}

Data 4 berisi informasi tentang kolonye atau splash cologne. Iklan tersebut dipasang di salah satu tiang besar di gedung sekolah. Materi iklan tersebut berupa plastik dengan ukuran kurang lebih 0,5 X $1 \mathrm{M}$. Iklan ini sangat jelas dan mudah dibaca oleh siapa saja yang berada di dekat iklan tersebut karena teks tulisnya sangat terbatas dan foto produk jelas terlihat. Sasaran iklan ini adalah remaja putri. Iklan ini sangat relevan dipasang di lingkungan SMP meskipun tidak langsung berhubungan dengan pendidikan.

Fungsi iklan ini bisa terlihat dari gambar atau foto yang dipajang berupa produk berbagai varian kolonye dan roll on Mustika Puteri. Remaja putri di SMPN 44 diharapkan menggunakan produk tersebut agar menambah wangi aroma tubuh mereka.

Dilihat dari kejelasan pesan dan manfaat iklan, teks iklan tersebut dapat dianalisis melalui informasi berikut. Kejelasan iklan dapat ditangkap dari informasi foto yang disampaikan. Dari segi manfaat teks tersebut dapat diuraikan melalui penjelasan berikut ini

$$
\text { Ilustrasi yang membantu }
$$
tampilan iklan tersebut adalah adanya perbedaan ukuran dan warna huruf. Dalam iklan ini tidak muncul karakter atau tokoh. Warna ringan yang ditampilkan mengesankan bahwa kolonye ini ringan dan menyegarkan 
Fungsi Sosial, Struktur, dan...

karena hanya mengandung minyak konsentrat 5\% saja. Baris pertama pada iklan ini diawali dengan slogan yang kontekstual. Pemberian warna merah yang mencolok dan besar menjadikan slogan ini mendominasi teks pada iklan ini. Selanjutnya iklan diikuti dengan produk barang yang ditawarkan. Baris pertama dan isi teks tulis tersebut sebenarnya tidak berhubungan langsung dengan isi iklan tersebut. Iklan ini hanya kontekstual dan cocok dipasang di sekolah dan tidak akan cocok dipajang di luar sekolah. Oleh karena itu, iklan ini menjadi sangat kuat dipajang di sekolah karena pesan konteks yang ada.
Fungsi iklan ini mengajak anak sekolah untuk menggunakan produk ini, tetapi masih terdapat pesan sosial lain disampaikan kepada warga sekolah untuk menghormati guru dan menghargai teman. Inilah fungsi sosial yang ditekankan iklan ini.

Struktur teks Data 4 dapat disampaikan melalui Tabel Struktur Teks Data 4 berikut ini. Struktur yang biasa dan lengkap dalam sebuah iklan meliputi orientasi^tubuh iklan^justifikasi. Untuk itu, pembagian struktur pada teks di Data 4 dapat dilihat sebagai berikut.

Tabel 4 Struktur Teks Data 4

\begin{tabular}{ll}
\hline Struktur Teks & Teks \\
\hline Orientasi & HORMATI GURU HARGAI TEMAN MU \\
\hline Tubuh iklan & Mustika Puteri \\
\hline Justifikasi & www.mustikaputeri.com \\
\hline
\end{tabular}

\begin{abstract}
Bagian orientasi teks iklan di atas berupa slogan yang tidak kontekstual dengan produk barang "HORMATI GURU HARGAI TEMAN MU". Bagian orientasi ini disampaikan untuk memberikan pesan yang sangat kontekstual dengan lingkungan lokus tersebut untuk menjalankan fungsi sosialnya. Mungkin iklan ini tidak akan dipasang di lingkungan komersial atau tempat perdagangan lainnya. Iklan ini
\end{abstract}

menjadi kontekstual karena bagian orientasinya. Bagian pembuka teks ini sebenarnya tidak berhubungan langsung dengan tubuh iklan. Yang menghubungkan dan memadukan iklan ini adalah kekuatan orientasinya.

Bagian tubuh iklan di atas berupa produk yang ditawarkan, yaitu Mustika Puteri berupa kolonye dan roll on. Tubuh iklan hanya memunculkan 
satu produk informasi saja dan tidak ditambahkan informasi lain.

Bagian justifikasi berupa informasi penjelasan produk hanya dimunculkan alamat laman www.mustikaputeri.com. Secara struktur iklan tersebut memenuhi ketiga bagian dari teks iklan berupa orientasi^ ${ }^{\wedge}$ tubuh iklan^justifikasi. Oleh karena itu, Data 4 dapat disimpulkan memenuhi semua bagian struktur teks yang lengkap.

Kaidah kebahasaan teks iklan pada Data 4 dapat diulas sebagai berikut. Teks iklan secara umum memiliki kaidah kalimat persuasif dan imperatif dapat dilihat pada slogan. Rima dapat dilihat pada penggunaan kata "guru" dan "temanmu". Struktur teks singkat dan hanya muncul satu kalimat dalam iklan tersebut. Teks Data 4 diawali dengan slogan yang sangat kuat untuk lingkungan sekolah. Inilah kekuatan iklan ini, meskipun barang atau produk yang ditawarkan tidak langsung berhubungan dengan dunia pendidikan. Sesuai dengan strategi pemasaran dari Arens dkk. (2010) bahwa produk barang ini termasuk barang kosmetik yang sangat relevan dengan usia remaja putri di SMPN 44 Jakarta tersebut. Slogan "HORMATI
GURU HARGAI TEMAN MU" salah satu penentu kekuatan iklan ini di lingkungan sekolah sebagai penanda fungsi sosialnya. Slogan inilah sebagai penentu bahwa iklan ini layak dipajang di sekolah. Slogan ini juga bersifat persuasif. Struktur kalimat yang digunakan berupa kalimat imperatif, "hormati" dan "hargai" yang berarti meminta orang yang membaca untuk melakukan itu. Makna kalimat tersebut sesuai untuk diterapkan di lingkungan sekolah terkait dengan sikap siswa terhadap guru dan teman-temannya. Meskipun slogan yang persuasif dengan kalimat imperatif, isinya tidak menyerukan ke produk barang yang disampaikan. Oleh karena itu, kalimat yang dibangun menguatkan konteks lokus atas produk tersebut.

Dalam iklan tersebut tidak digunakan kata ganti orang. Tidak ada teks tulis selain slogan dan produk barang. Ini juga menjadi satu kekuatan kesederhanaan yang kuat. Karena bersifat pengedepanan informasi iklan tersebut tidak menggunakan ejaan yang sesuai dengan PUEBI. Hal itu terlihat dari penggunaan huruf kapital pada semua huruf, ketiadaan tanda baca, dan pemenggalan kalimat yang tidak tepat. 
Fungsi Sosial, Struktur, dan...

\section{Data 5}

Data 5 berisi informasi tentang kolonye atau splash cologne. Iklan tersebut dipasang di salah satu tiang besar di gedung sekolah. Materi iklan tersebut berupa plastik dengan ukuran kurang lebih 0,5 X 1 meter. Iklan ini sangat jelas dan mudah dibaca oleh siapa saja yang berada di dekat iklan tersebut karena teks tulisnya sangat terbatas dan foto produk jelas terlihat. Sasaran iklan ini adalah remaja putra, jadi iklan ini sangat relevan dipasang di lingkungan SMP meskipun tidak langsung berhubungan dengan pendidikan.

Fungsi iklan ini bisa terlihat dari gambar atau foto yang dipajang berupa produk tiga varian kolonye. Remaja putra di sekolah diharapkan menggunakan produk tersebut agar menambah wangi aroma tubuh mereka. Iklan menjadi relevan dengan lingkungan sekolah karena diawali dengan slogan yang cukup dekat dengan masyarakat sekolah, yaitu "SemangattMU Adalah PrestasiMU". Slogan berprestasi tentu sangat kontekstual dengan lingkungan sekolah.
Pesan slogan tersebut secara umum disampaikan kepada semua warga sekolah, khususnya siswa yang belajar di SMPN 44 Jakarta. Pesan ini tidak hanya sebagai pesan untuk sasaran iklan itu, yaitu siswa putra, tetapi disampaikan juga kepada semua warga sekolah, termasuk siswa perempuan. Inilah fungsi sosial yang ditangkap dari iklan ini. Pemaknaan yang lebih khusus adalah jika siswa putra menggunakan kolonye BASK akan menjadi semangat dalam belajar, beraktivitas, dan berkegiatan di sekolah. Dengan adanya semangat dalam semua aktivitas itu membuat siswa SMPN 44 Jakarta akan meraih prestasi. Oleh karena itu, fungsi sosial iklan ini dapat dipandu dari awalan slogan yang dipajang. Fungsi sosial iklan ini memberikan pesan untuk meningkatkan prestasi.

Struktur Teks 5 dapat disampaikan melalui Tabel Struktur Teks Data 5 berikut ini. Struktur yang biasa dan lengkap dalam sebuah iklan meliputi orientasi^tubuh iklan^justifikasi. Untuk itu, pembagian struktur pada teks di Data 5 dapat dilihat sebagai berikut. 
Tabel 5 Struktur Teks Data 5

\begin{tabular}{ll}
\hline Struktur Teks & Teks \\
\hline Orientasi & SemangatMU Adalah PRESTASIMU \\
\hline Tubuh iklan & Bask for Men \\
\hline Justifikasi & $\begin{array}{l}\text { WANGINYA PAS! } \\
\text { www.baskformen.com }\end{array}$ \\
\hline
\end{tabular}

Bagian orientasi teks iklan di atas berupa slogan produk yang tidak langsung berhubungan dengan produk yang dipasarkan "SemangatMU Adalah PRESTASIMU”. Bagian orientasi ini disampaikan untuk memberikan pesan yang sangat kontekstual dengan lokus sekolah yang berhubungan dengan semangat dan prestasi dalam belajar. Iklan ini tidak akan di pasang di lingkungan komersial atau tempat perdagangan. Iklan ini akan lebih kontekstual dipasang di lingkungan sekolah atau arena olahraga. Iklan ini menjadi kontekstual karena bagian orientasinya. Yang menghubungkan dan memadukan iklan ini adalah kekuatan orientasinya.

Bagian tubuh iklan di atas berupa produk yang ditawarkan, yaitu Bask for Men berupa produk kolonye. Tubuh iklan hanya memunculkan satu produk informasi saja dan tidak ditambahkan informasi lain.

Bagian justifikasi berupa slogan penutup dan informasi penjelasan produk alamat laman www.baskformen.com. Iklan ini ditutup dengan slogan "WANGINYA PAS" memberikan informasi kepada pembaca atau sasaran bahwa wangi kolonye tersebut cocok dan sesuai dengan anakanak atau siswa SMP. Wangi kolonye ini tidak berlebih yang mengesankan deodoran atau minyak wangi yang berat dan mengesankan untuk laki-laki dewasa. Secara struktur iklan tersebut memenuhi ketiga bagian dari teks iklan berupa orientasi^tubuh iklan^justifikasi. Oleh karena itu, Data 5 dapat disimpulkan memenuhi semua bagian struktur teks yang lengkap.

Kaidah kebahasaan teks iklan pada Data 5 dapat diulas sebagai berikut. Teks iklan secara umum memiliki beberapa kaidah kebahasaan dengan penonjolan penggunaan dua slogan. Slogan pertama yang berhubungan dengan lokus tempat sekolah dan slogan kedua yang berhubungan dengan produk yang dipasarkan. Teks iklan Data 5 diawali dengan slogan yang kuat untuk lingkungan sekolah sebagai fungsi 
sosial. Kepersuasifan teks ini diwakili kedua kalimat yang ada. Rima $u$ sengaja diambil yang diwakili kata "semangatmu" dan "prestasimu". Kedua kalimat juga sangat singkat dalam kalimat simpleks. Inilah kekuatan iklan ini meskipun barang atau produk yang ditawarkan tidak langsung berhubungan dengan dunia pendidikan. Namun, slogan ini juga dihubungkan dengan produk barang yang dipasarkan. Slogan ini menggunakan kalimat deklaratif dan bukan imperatif, tetapi makna slogan pertama bersifat persuasif. Pembaca membenarkan dengan pernyataan bahwa semangat berhubungan dengan prestasi atau prestasi diawali dengan semangat. Sesuai dengan strategi pemasaran dari Arens dkk. (2010) bahwa produk barang ini termasuk barang kosmetik yang sangat relevan dengan usia remaja di sekolah. Slogan kedua "WANGINYA PAS” merupakan slogan yang berhubungan langsung dengan produk yang dipasarkan. Slogan kedua menyatakan bahwa produk tersebut cocok dan sesuai dengan selera anak muda yang ringan. Pas bermakna cocok dengan anak muda yang tidak seperti parfum yang berat yang digunakan oleh lelaki dewasa. Oleh karena itu, slogan kedua meskipun ditulis lebih kecil daripada slogan pertama, slogan inilah yang menyokong produk langsung tersebut. Dalam iklan tersebut tidak digunakan kata ganti orang. Karena bersifat pengedepanan informasi dan bukan kalimat resmi, iklan tersebut tidak semuanya menggunakan tata ejaan yang sesuai dengan PUEBI. Hal itu terlihat dari penggunaan huruf kapital yang tidak beraturan dan sebagian kalimat tidak menggunakan tanda baca.

\section{Penutup}

Teks iklan di SMPN 44 bukan merupakan teks yang dominan di lanskap sekolah. Dapat disampaikan bahwa ranah produk iklan yang telah dianalisis di SMPN 44 Jakarta berhubungan dengan pendidikan, minuman, dan kosmetik. Semua iklan yang dipajang di SMPN 44 Jakarta semua menggunakan komposisi warna dan besaran huruf yang berbeda. Slogan pada semua produk barang ditulis dengan ukuran huruf paling besar dan kalimat pembuka untuk produk jasa ditulis dengan ukuran huruf paling besar. Tiga dari lima iklan yang dipajang selain mengedepankan fungsi iklan sebagai media pemasar, juga mengedepankan fungsi sosial dalam 
konteks pendidikan. Oleh karena itu, fungsi sosial iklan juga dominan terlihat pada iklan di sekolah.

Dilihat dari struktur teks iklan empat dari lima teks memiliki struktur teks, orientasi, tubuh iklan, dan justifikasi dan hanya satu teks iklan yang memiliki struktur tubuh teks dan justifikasi.

Penggunaan bahasa di iklan yang terpasang di SMPN 44 Jakarta sebagian besar menggunakan slogan dan hanya satu yang tidak menyampaikan slogan. Bahkan, dua dari lima iklan menggunakan dua slogan. Oleh karena itu, slogan merupakan bagian penting yang harus hadir dalam sebuah iklan. Tiga iklan menggunakan kalimat imperatif dan dua iklan menggunakan kalimat deklaratif. Empat iklan menggunakan kata berima dalam slogan yang digunakan. Satu iklan menggunakan kata ganti pertama 'kami'. Tiga iklan lainnya tidak menggunakan kata ganti orang. Sebagian besar iklan tidak menggunakan kaidah PUEBI terutama dalam pemakaian tanda baca dan huruf kapital. Kalimat yang digunakan sebagian besar berstruktur kalimat simpleks sesuai dengan prinsip kesederhanaan pada teks iklan.

\section{Daftar Pustaka}

Agustien, Helena, I.R. 2020. Implementing a Text-Based Appproach in Eglish language Teaching. Malang: TEFLIN Publication Division in collaboration with Bintang Sejahtera Press.

Arens, Williams dkk. 2010. Contemporary Advertising and Integrated Marketing Communications. New York: McGraw-Hill/Irwin.

Brown, Kara D. 2005. Estonian Schoolscapes and The Marginalization of Regional Identity in Education. Jurnal European Education, 37(3), 7889.

https://doi.org/10.1080/10564934. 2005.11042390.

Gorter, Durk dan Jasone, Cenoz. 2015. Linguistic Landscapes Inside Multilingual Schools (O. I. B. In B. in Spolsky, M. Tannenbaum, O. Inbar (Eds.), Challenges for language education and policy: Making space for people. (pp. 151169). New York: Routledge Publishers .

Hewitt-Bradshaw Irish. 2014. Linguistic Landscape as a Language Learning and Literacy Resource in Caribbean Creole. Jurnal Caribbean Curriculum No. 22, 157-173.

Kosasih. 2017. Bahasa Indonesia SMP/MTs Kelas VIII. Jakarta: Kementerian Pendidikan dan Kebudayaan. 
Landry, Rodrigue dan Richard Bourhis Y. 1997. Linguistic landscape and ethnolinguistic vitality: An empirical study. Journal of Language and Social Psychology, $16 \quad$ (1), 23-49. https://doi.org/10.1177/0261927X 970161002.

Maulidina, Yulinar Rahmawati dan Trinil Dwi Turistiani. 2018. Pengembangan LKPD Menggunakan Model Pembelajaran Langsung (Direct Instruction) untuk Materi Teks Iklan Kelas VIII. Jurnal Bapala, 5 (2), 1-10.

Mayring, Philpp. 2000. Qualitative Content Analysis. In Forum Qualitative Social Research (Vol. 1 , Issue June).

Sayer, Peter. 2009. Using the Linguistic Landscape as a Pedagogical Resource. ELT Journal, 64 (2), 143-154.

https://doi.org/10.1093/elt/ccp051.
Scarvaglieri, Claudio. 2017. Educational Landscaping: a Method for Raising Awareness about Language and Communication. Jurnal Language Awareness, 26 (4), 325-342. https://doi.org/10.1080/09658416. 2017.1411358 .

Shulz, Don E. dkk. 1996. Essentials of Advertising Strategy. Lincolnwood (Chicago): NTC Business Books.

Sudarwati-Grace. 2016. Pathway To English 1. Bandung: Erlangga.

Tugiati, Tutut dan Kuntoro. 2019. Teks Iklan Naratif (Analisis: Isi, Struktur, Butir Kebahasaan, dan Implikasi dalam Pembelajaran Bahasa Indonesia Kelas VIII SMP. Hasil Penelitian dan Pengabdian pada Masyarakat IV Tahun 2019, 342-350. 